\title{
Objectification and Instrumentalization: The Activation of Thanatos in Connection with "Body-Power"; or the Human Body as a Critical Object of Power in the Recent Social Reality
}

\author{
Yana D. Nikolova ${ }^{1}$ \\ ${ }^{1}$ Independent Researcher, London, United Kingdom \\ Correspondence: Yana D. Nikolova, independent researcher, London, United Kingdom.
}

Received: March 29, 2021

Accepted: May 24, 2021

Online Published: October 8, 2021

doi:10.5539/ijps.v13n4p1

URL: https://doi.org/10.5539/ijps.v13n4p1

\begin{abstract}
This paper is about the ways in which the human body has been objectified under and through the use of power. The article explains the different aspects and ways of objectification of the body and the hidden nature of human behaviour that results from activation of the inner human instincts - the death drive, called Thanatos (Note 1) and the life drive called Eros as a response to Thanatos. By using the theories of Freud, Nussbaum, Erikson, Fanon and Foucault, the relationship between the human body and external power is examined. Using some recent events (such as the Covid-19 pandemic, the world lockdown and the Black Lives Matter movement) human behaviour is seen to result from activation of the inner drives (Eros (Note 2) and Thanatos), but also to be linked to the psychosexual and psychosocial aspects of human development.
\end{abstract}

Keywords: human body, object, objectification, drive, instincts, power, human behaviour, Eros, Thanatos, lockdown, pandemic, psychosocial, Black Lives Matter movement

\section{Introduction and Concepts}

Objectification is a process, yet a famous feminist concept, that defines a way of treating a person as an object. Of course, over the years, directly and indirectly the human world has witnessed this phenomenon in many different forms and in many different realms. The most disturbing nature of this phenomenon is the moment of dehumanization (Note 3) within it. According to Martha Nussbaum, who argues about the problematic nature of ways of treating human beings (mainly with reference to women in her theory), there are seven features in this social phenomenon of objectification. These are instrumentality, denial of autonomy, inertness, fungibility, violability, ownership and denial of subjectivity. All of these involve the idea of treating the person as an object and dehumanize (Note 4) the body. Nussbaum identifies different ways of treating a person: as a tool for specific purposes, as lacking autonomy and self-determination, as lacking activity, as being used interchangeably with other objects, as lacking boundaries, as being owned by another and being taken as "something" whose experiences and feelings need not be considered. Revising Nussbaum, Rae Langton has added variously to this list: as a person identified with their body, a person seen on the basis of how they look and treating a person as if they have no capacity to speak (Stanford Encyclopaedia, 2010). Looking more deeply into all of them it may be seen that they have in common a moment of fragmentarization of this objectification, which involves treating a person as a body and treating the body as an object. The link between these two is an instrumentality in use that demonstrates unconscious moments of complex human behaviour appearing in the collective reality. Moreover, objectification can be applied not only to women, but also to collective groups. This article aims to expand the objectification theory by applying it to some collective events. It also aims to outline and analyse some of Nussbaum's and Langton's features of objectification of the body, considering recent social and political events in the public sphere. Furthermore, the article aims to explain objectification through the use of power as a main instrument and how objectifying the body is one aspect of the inner human death drive and the nature of psychological human existence.

\section{The Body in the Discourse}

The human body has been a central focus of many areas of exploration and at the same time it has been the main tool to define various biological and social constructs such as sex, gender, race, ethnicity, and personal and national identity. The body has played an important role in making social changes. Examples of these are 
feminism, rights for equality in terms of races, sexuality, reproduction, workforce, sickness, epidemics, pandemics and their spread across the globe. These moments of change have remained historically significant and marked beginnings of new eras, as any type of science is based on a change of perception about life and the human body. Visibly, art, science and medicine perform, represent and transmit to society all explored knowledge in different forms: science and medicine in particular, awakening in and for humans, appear mainly in relation to the body's existence and survival. The area of social science is the most sensitive to perceptions of the human body because physically and socially the body works in settings, surrounded by objects with which it interacts. Also, the body is seen through the links with life, death, well-being, life after death and all concepts introduced by philosophy, religion, psychology, history, anatomy and medicine.

From a psychosocial angle, the main areas of exploration and studies linked to the human body are authority and power, hierarchy and fear. Being in a public space they are linked to resistance, relationships, gender, sexuality, normality and abnormality. In combination, they show how the body is seen through different discourses and perspectives, in the way the culture of art, music, theatre, literature and different movements represent it. Although the human body is seen in many different areas from many different discourses, the body being examined in its social, political and economic way is an idea that has been studied and analysed for decades and generations. In postmodern society (through the work of Michel Foucault), the body is seen in its interaction with institutions of power, which gives a physical and social discourse. However, in comparison with its modern position, the human body in the past was described and analysed (mainly by Frantz Fanon) as a colonized body which develops identity through recognition by others. In contrast to that, Freud sees the body as an organization of the mind through which it performs human actions with symbolic significance. The two Freudian concepts of Eros (life drive) and Thanatos (death drive) come to explain a lot of social conflicts in nature - moments in human reality where the body positions itself alongside of being positioned externally, based on its urgently recalled instincts, but is also used as an instrument by any type of power. These different positions of the human body, established by different power dynamics, will be evaluated by comparing and contrasting why, where, how, from what perspective, through which interaction and in what relation the human body is exploited or used to create a conflict (war, pandemic, colonization - all related to human rights, democracy, freedom, death, Thanatos) that leads to its becoming an instrument of power. Furthermore, these positions will be seen in Nussbaum's theory of objectification to explain how modern power has objectified the human body in the postmodern reality.

\section{The Foundation of 'Body - Power' in Literature}

In his book "Discipline and Punish", Michel Foucault sees the human body as "the major target of penal repression" which later on disappears slowly with the fading of the theatrical public punishment as " $a$ spectacle" (Foucault, 1979, p. 8). However, exactly like the prison, the social reality becomes a place of power. During the Covid crisis, the lockdown managed human freedom. It could be seen as the place where the body was held to experiencing the power of the state, to feel the power, to be aware of it and to learn from it. The practices of punishment appeared as a symbol of power. That shows the interaction (body-power being so placed) between institutions as a mechanism of power, power itself and the human body which is punished by this power, as represented by the prison as an institution of social control. Therefore, the body is somehow objectified by power, changing its position from the "body of condemned" or the punished body under physical pain to the "docile (receptive) body" (Foucault, 1979, p. 13) under capital pain which establishes a whole new set of ethics and rules to which the body has to adapt, accept and take as the way of setting a new order. Seen from a new discourse, the human body has started to represent new ways of interaction with the institutions of social control which have been part of a strong long-term punishment provider - the state apparatus. It has seen the body as an object to which punishment can be given in another form - hurting the soul through thoughts, penalties, debts, fees, mortgages, credits, bills, etc. (Foucault, 1979, p. 16). Even death. Therefore, in the postmodern reality, Foucault sees deeply the body-power connection in his explanation about the body being politically involved, engaged, and challenged in practices serving the state, which uses the body as a workforce first and second as a "political instrument" (Foucault, 1979, p. 26). However, in this way the body becomes the instrument of power and has been objectified in two main ways - Nussbaum's denial of autonomy, in which the person lacks autonomy and self-determination, and Langton's silencing moment of objectification, during which there is no capacity to speak. Therefore, through the 'power-body' connection, Foucault outlines the 'power-knowledge' connection, in which he sees how both "directly imply one another" (Foucault, 1979, p. 26) - as knowledge is a tool which works to establish power and to objectify the body. To this connection, Foucault links the term 'discipline', which comes to see the body as a "target of power". In simple terms, that means the power (the state) decides to take away freedom of movement of the body and puts restrictions on actions, space and time by establishing control through a new law or regulation. The restrictions and reductions (being in direct opposition 
to freedom) exercised through power activate different types of destructive behaviour, such as public fights, protests and violence. Discipline (exercised through the institution of social control - the police) becomes a powerful tool of the state and its aim at the same time is to reinforce itself in many ways, so that the body becomes punished, used, tortured, manipulated and changed through a transformation of techniques that are used to control and here the body is seen in its social interaction, being unable to experience itself fully. This is what the world of bodies experiences when it is held and regulated by the state. And when the existing body does not experience its moments of freedom, the drive of Thanatos is more easily activated and the sustaining drive of Eros appears as a natural human response.

\subsection{From Being a Product of Power, through an Object of Power in the Past to the Empowered Body at Present}

One of the most gendered views of the body is the one explored by Feminism, which points out that, seen as a "concrete phenomenon" (McNay, 1992, p. 17), the human body is not only objectified by power and regulated by it, but is also gendered. There is a point where the body is passive while being active - being regulated externally while existing. This makes it a tool. The body is the main place where power is concentrated in modern society in the exercise of social control. In a situation of war or any other national emergency, for example, the women are first protected alongside the children. During a mass death, the statistics and the media news always provide numbers for female (and children's) bodies affected (Hutt, 2020). Thus, the female body is seen in two ways: one of these being as a reproductive source, connected to other bodies. So, looking at the body from a social perspective rather than a biological one implies more focus on the self than on the self-others connection as a means of establishing identity. Foucault sees sexuality as a topic of his investigations to prove not only that "the body is directly targeted and 'produced' by power", but also that it is "unknowable outside of its cultural significations" (Armstrong, 2021), in which statement Foucault makes the clear the difference between biological sex and socially constructed gender. Thus, the body can be seen as a directed, structured and examined object that is also changed by transformations in moral codes. Therefore, the body becomes a matter of interest and acts as a focus of morality, appropriateness and mainly as a focus of historical situation as a socially constructed term. In "History of Sexuality: Volume 1 and 2" the body is under discussion in its social and historical context. Many constructions are linked to what sex and sexuality are and how both define an attitude, structure moral experience and create identity; and this is seen through different practices and experiences during the history of old civilizations such as the Greeks and Romans. These practices place certain "regimes" in relation to others. Therefore, sexuality is seen "as a complex historical system of discourse saturated with power" (Alessandrini, 2009, pp. 64-80) and as power and destruction. This view opens the door to discussion of the body in its moments of the rise of Thanatos. According to Nussbaum, objectification "refers to the fragmentation...into a collection of sexual parts and/or sexual functions, essentially stripping her of a unique personality and subjectivity so that she exists as merely a body" (Cologero, 2012, p. 574). Even though Nussbaum refers her theory mainly to female bodies, there is a degree of relevance in a collective sense. This comes from the fact that there is a moment of "monitoring" coming from both the internal source - the self or "self-surveillance" and from the external source - the state and its representative agencies (such as police, local authorities, etc.). Therefore, the body "represents the behavioural manifestation" (Cologero, 2012, p. 575), the self- and the non-self-objectification in various ways - Nussbaum's ways being use for the purposes of others (instrumentality) alongside lacking autonomy (denial of autonomy), and Langton's, reduction of the body, where the person is identified with their body or body parts (reduction to body) (Stanford Encyclopaedia, 2010). Seeing sexuality as a discourse, the moment of objectifying by sexualising the body is the moment of activating Thanatos. However, the body is again put into the position of being a focus of power because of the reflection of moral codes on the transformations of the body, which leads to increased distrust of pleasure and any sexual activity - and that is the focus of the "care of the self". The term '"care of self" has various points linked to the first-time, indirectly mentioned, concept of identity, these being individual freedom and the body-soul link. Individual freedom of being is interlinked with freedom of self-care, in which momentum the body experiences its fundamental emotional, physical and social needs. So, for Foucault, the body is not only in an interaction of power, but also in an interaction with others through power. This confirms that power lives everywhere - in every human relationship and in every interaction - which slowly leads to the concept of a sense of self-identity being one of the most important areas of exploration in contemporary society and the area most touched and explored by power itself, especially how the body reacts under restrictions on using space and movement (referring to the world pandemic in 2020). When the body is restated in the physical, the self is affected by loss of experience of the environment that the self identifies with, and by the minimized opportunities of demonstrating care of self (especially restrictions on accessing gyms, leisure centres, shopping malls, public events being forbidden during the lockdown in most countries across the world). This dissolution of life, or in other words activation of Thanatos, is caused by the repression of human rights, freedoms and forms of self that, 
in Freudian language, could be taken as an objectified meaning alongside the social environment. Being "obliged to reject the urges that cannot conform to reality" (Kli, 2018, p. 73) the human Ego, as the most active part of the personality, "perceives, interprets, and recasts reality according to its interest" (Kli, 2018, p. 73). It represents the drives, but it can also transform them from one into the other. Therefore, "the Ego runs the risk of becoming itself the focus of the Death drive and thus being annihilated. Hence, it is summoned to transform into a representative of Eros, that is, to invest itself with libido, which results in the desire for love and life" (Kli, 2018, p. 76). Therefore, the human body as an object of power represents the link between power, oppression, repression and drives and still "contends that its first experience of pleasure is a sexual one" (Kwon, 2007, p. 131). Hence, following Foucault who sees "sexuality is constructed and discursive", the conceptualizations of the body (seen by both Freud and Foucault in a similar way) "extends the Freudian notion of the death drive to the public fantasy created by films and its relations with spectators" (Kwon, 2007, p. 133). An example is the protesting and mass demolition of monuments during the Black Lives Matter movement - monuments that represent a type of power from a keenly felt past, full of oppression, aggression and death in which the human body has its central place. This is a collective reaction to the body (coming from the life drive) being owned, being silenced, being objectified and instrumentalized, being seen as interchangeable with other objects and at the same time being seen on the basis of how the body appears to the senses. Moreover, "the habitual body monitoring.... may induce body shame and appearance anxiety, which represents psychological states that are difficult to alleviate" (Cologero, 2012, p. 576). And as the death drive is activated, violence comes to be the natural response to objectification and instrumentalization of the body, especially when power is involved and exercised by humans on humans. This is leading towards another way of objectification of the body - being used as a tool for the objectifier's purposes. In the case of George Floyd, for instance, power and status were manipulated or seen as such by the public.

\section{The Black Lives Matter Movement - the Response of the Objectified Body from the Past Experiencing a New Power Struggle}

The human body has suffered tremendous disasters throughout history such as epidemics, wars, genocides, natural disasters (earthquakes, hurricanes) and the 2020 pandemic. One of the human disasters most loaded with cruelty, violence, conflict and pain is colonization and the slave trade. The human body was seen and used not only in a sexualized social way through power, but by a different type of power - the power of colonization. This locates the human body in another discourse - still dehumanized, as in the Foucauldian one, but within another subjectivity. Whilst Foucault sees the body as a concentration of power, creating its identity through interaction with power in a fully social context, Fanon sees a violated body, which suffers in different way based on its colour and which creates its identity through recognition of the "other". Therefore, Frantz Fanon locates the human body in a more political context, with a social and psychological outcome, being part of the post-colonial period. Moreover, he hints at another power which is concentrated on the body: the political power of the process of colonization, through which the body becomes subject to violence. The colonized body from the past is seen in the process of not only being physically colonized, but also mentally invaded by structuring ideas in which colour holds the moment of power. However, in the idea of the colonized, dehumanized, violated body (looking at it as Foucault did, historically and socially), the colonized body hints at another idea about identity at a personal level (an object which is produced by and serves political and social reality), and at the process of depersonalization on a general level (not being recognized as a body distinct from others), as well as the identity developed in the colonized-colonizer relationship. This brings to the fore the destructive nature of a conflict that has been in the air for decades. Moreover, it brings additional conflicting oppositions that have a dangerous power dynamic. To be destroyed, the symbols of it need to be removed and this explains why the public during the Black Lives Matter movement in 2020 started destroying the statues of the colonizers as "still alive" figures that bring history back to life by reminding through remembering. Furthermore, these oppositions open hidden conflicts that bring humans closer to the death drive (by expressing negativity, destruction, risky behaviour, self-harm, killing and mass murder). Therefore, to activate Thanatos is to perform a 'born-to-die approach' after which the death drive rises as a response to inner human conflicts and outer political and social issues through strikes, violence, rioting and other aggressive, collective destructive behaviour. In a form of protest, the body enters the public sphere where it interacts with other bodies for a cause that is related to destruction. And the cause dissolves the meaning of colour even though there is an interaction with it. Thus, "a tendency toward violence and dissolution was apparent" (KLi, 2018, p. 71). And again, recognition of the body and identity has been developed in relation to the connection with others, through Fanon's 'I-They' identity model, in which "I" as colonized from the past "can never identify" (Fanon, 1986, p. 23) with "I" from the present, but can always be reminded of it. As "the individual psyche in Freudian psychoanalysis appears in constant conflict between, there is a dynamic that develops between the two main forces" (Kli, 2018, p. 70). This brings inner conflict of 
the self, which can easily activate Thanatos by going inwards (expressing that in self-harm, suicide, etc.), or going outwards (expressing it in fights, aggression, killing, war). Whatever the drive leads the body towards, one thing will be constantly present- the natural human instinct to survive as a response to Thanatos, or, in Freudian language - Eros, the desire to live. The activation of Thanatos through the Black Lives Matter movement is seen in how the human body reacts to social and political triggers. The reactions are in the direction of three main concepts - identity, domination and freedom. The protesting body lives its identity, and experiences conflict, through interaction with others in the public sphere, aiming to reduce racism as an established division within society. The anti-racist protest becomes "an obligation to return to the other that which racism has taken away" (Binkley, 2016, p. 1). Therefore, the Black Lives Matter protest is a result of manifest domination by a representative of an institution of social control, exercised through the "body-power" connection and applied through demonstrating power over the human body. The search for recognition at present turns into the search for complete freedom, as the objectified body examines its identity through power relations. Whatever form it takes, the search for freedom of the human body provides opportunities for a change of power in a political and social way. Limiting freedom through exercising power can become extremely destructive. Hence, Thanatos can rise above Eros, especially if power is applied through domination (an example is the scene of the police officer killing George Floyd). The objectification in this particular case is, according to Nussbaum, denial of subjectivity (the person's feelings are not considered), but mainly instrumentality, in which the person is objectified by being used as a tool for the objectifier's purposes. In this context, objectification is to be contemplated together with "issues related to personal safety, and interpersonal relationships"; for "feelings of helplessness associated with worry and lack of control in these critical areas may contribute to feelings of depression" (Cologero, 2012, p. 576) - at a collective level. This can be clearly seen in relation to the Black Lives Matter Movement, and through the terms "power" (used by Foucault) and "race" (used by Fanon). However, in the work of postmodernism, power is seen in domination and violation by the agents of social control (institutions); and in the work of the phenomenologist Fanon, power is seen in the domination of one race by another. Both forms of power are seen in embodied experiences which structure identity and limit freedom. Therefore, the postmodern pandemic today can be viewed in two ways - freedom is limited by imposing power from the state so that the body becomes a violated body, unconscious of the rise of Thanatos within itself. In this moment the term "humanity" can be seen in the hidden discussion of what man is and how he exercises his human rights. This idea is linked with freedom, viewed (by Fanon and Foucault especially) as a struggle. In the "myth" of "Man and Society", the "alienation of identity" is seen in the segregation of body and soul, forming the "process of identification" (Fanon, 1986, p. 27). In the concept of power relations, and in "History of Sexuality", Foucault connects society to the psychoanalytical link 'body-mind-power'. Fanon clearly discusses psychoanalytical processes such as neurosis and the Oedipus complex, as well as discussing the relations of body, soul and power in the idea of identification, making clear links to the work of Freud. Within the activation of Thanatos experienced during and after the pandemic in 2020, the body has clearly been directed to the inner connection with the self, and this connection brings out the worst in the human nature. Fears, sadness, worries, traumas, depression, neurosis, psychosis, violence, aggression, and so on activate the 'approach to death', in which the human body finds itself limited, isolated, violated and self-destructed. A clear example in recent reality is the Black Lives Matter movement that started after the lockdown in the US and quickly spread throughout Europe. In its nature, it was an expression of human sadness, outrage and despair related to the experience of death across the world due to the pandemic. Considering the time of the global pandemic, when lockdowns were claiming all lives matter, the moment of power struggle and loss of freedom directed the process of objectification to Black Lives Matter, where the body entered a new power struggle. And this time more individualized. Therefore, that mass habitation in death for a couple of months, together with freedom being taken away by an external body of power (the state), put the human population into a personification of death. This moment manifested itself in controlling risky and aggressive behaviour during the pandemic. However, when Thanatos clearly appeared in the killing of George Floyd as a visible physical action, this turned into an individual rights struggle. As an outcome of this action, the Black Lives Matter movement started to become a response of awakened emotions of past objectification. A present event evoked past experience of the objectification of ownership ("treatment of another as something that is owned") (Cologero, 2012, p. 575), alongside denial of subjectivity ("treatment of another as something whose feelings and experience do not need to be considered") (Cologero, 2012, p. 575) and the collective emotions attached to it. And while the sexualized body representing self- and non-self-objectification, lacks autonomy, the colonized body is linked mainly with the moment of ownership, where power and status play the main role. In both ways of objectifying the body, the primary psychological mechanism that accounts for the experience-objectification link is the destructive nature of the death drive, being exercised at a cultural, social and subjective individual level. And because of that, 
examples such as the Black Lives Matter movement have their peaks in the destruction of symbols related to domination, power and oppression of the human body in the past. And because this awakens the old ways of objectification of the human body, the Black Lives Matter movement has mobilized a new paradigm in the power dynamics between the body and public institutions. The reason for this is the moving of attention from global to local 'life matters' by provoking a "national uprising" in the US (Schwab, 2020). This social unrest demonstrated the "collective human dynamic and frame of mind" (Schwab, 2020). But it also showed how social factors can provoke underlying conditions to evoke the human Thanatos.

\section{The Pandemic of Covid-19: the Feelings of Shame and Disgust by the Instinctive Body in Its Anal Stage. 'Reduction to Body' Objectification}

Freud brings something new and deep into the link between the concepts of "body-mind-power". He discovers and unveils the motivations and experiences of the human psyche which he calls libido and its power over human behaviour. He defines the libido as a representation of the union between body and soul, but at the same time he discusses neurosis as well, looking at cases from a personal, deep perspective, which somehow finds its way from the psyche out to its social reality. So far, we have seen the body as "violated" and "alienated" through interaction with power or through recognition of others in a model of relation between the body and its surroundings. Freud sees the body in a different way. His focus is on the body as a place of instincts for love, happiness, pleasure and social interactions. The body in the works of Freud is mainly "libidinal", pleasurable, sensual, "erotogenic" and a place of compelling needs which direct its behaviour in a social environment (McNally, 2001, p. 8). The body suffers from itself- from its ego, id and alter-ego. In comparison to Fanon and Foucault in whose works the 'violated body' suffers from the interaction with power, institutions, the exercise of certain forms of discipline, or simply from colonialism and its issues, in the work of Freud the body suffers from within, but is expressed without. This is a situation in which once the body has no freedom to move (as it has been ordered to position itself in a particular space for a period of time such as staying at home or being in prison), it starts to activate its inner instinct. During a time of stress (which triggers the most hidden human fears) the body experiences a regress to a less developed state and acts instinctively and irrationally. In this case the body enters a crisis. The pandemic has been a world health crisis that mainly affects the human body by objectifying it through its instincts, whilst the lockdown has become a human crisis that mainly affects the human rights of movement and freedom. One appears after the other, but both of them trigger the moment of control and exercise of power. They are interlinked in the process of objectifying the body through separating it from its identity and focusing on its parts, health and well-being. In other words- reduction to body objectification or "the treatment of a person as identified with their body, or body parts" (Stanford Encyclopaedia, 2010). The pandemic has provided the right social conditions to encourage people to conform to "projective expectations". Rae Langton argues that the projection of power is linked to a background of social conditions of unequal power. In the situation of the pandemic, social conditions made power unequal as people were not asked what to do, but the state has decided what to do. Therefore, control over the body and its parts has been lost by the people themselves due to an external object- a virus. This creates a fear in humans for keeping and being alive, for existing at a physical level. In addition, personal power over personal life has been taken away by the state and returned as an order or in other words as a "measure" "justifying the use of special powers that should be limited in time" (EU Parliament, 2020). The human body finds itself in a situation where "a state of emergency may be declared in the event of imminent danger resulting from serious breaches of public order, or in the case of events that by their nature and gravity endanger the public order" based on "de jure and de facto justifications" (EU Parliament, 2020). Being subjected to a state of emergency, the body also enters a state of defence in which its instincts, mechanisms and demands for control and autonomy start to arise. As control and autonomy are first experienced in the Freudian Anal stage, the human regresses to that stage of development by experiencing the fear and stress of doing one important task- establishing control of the bladder. According to Freud, pleasure has been moved from the oral to the anal side, where a sense of control over cleanness operates. Achieving this control and cleanness brings a sense of accomplishment and body independence. The fact that the first urgent reaction of people in many parts of the world before the start of and during the early days of the pandemic was buying toilet paper, indicates that the human population is massively losing control- the loss of control over their bodies and their lives. Control is established through power. Loss of control appears to be triggered in a situation of emergency when the body starts to operate through its instinctive first-signal system. In this case power has shifted, being removed from an individual to an external body (the state). In this situation, the human body activates its instincts to survive by establishing control. Moreover, the number of deaths (represented in percentages and statistics) brings fear for capability and control of personal life and survival. Thus, before and during the pandemic, a human life has been objectified by becoming a number. The objectification happens in various ways. Firstly, the body has been objectified by its instincts, becoming 
submissive to their power. Secondly, applying Nussbaum's theory, objectification continues in the public sphere in other ways: as instrumentality, as the body has been used by power for its own purposes (to impose certain behaviour through rules and regulations during the pandemic, for example, and ordering a lockdown later on); as inertness, as the body has no space for action; as ownership, as the body has been owned by the power of the state and therefore directed in its actions and being; as denial of subjectivity, because feelings have not been taken into consideration. And as power imposes a state of emergency, the body, applying Langton's theory, has been objectified by silencing throughout, by means of various objectifying attitudes such as presenting numbers, drawing conclusions, comparing statistics, etc. (Langton, 2011). When the number of deaths rises, the fear of losing control over life increases and the body reacts more impulsively (instinctively) than rationally. Therefore, impulsive actions such as buying toilet paper demonstrated human loss of control, the fear of instability and the loss of a sense of predictability, in a neurotic state of panic unconsciously concerned about managing a sense of cleanness. At the same time an inner psychosocial conflict starts to arise- the conflict between autonomy versus shame and doubt. This becomes a psychosocial crisis, which has maladaptive tendencies - impulsivity and compulsion (Boeree, 2016, p. 7). This demonstrates how people can identify with their body or body parts which leads to Langton's 'reduction to body' objectification.

Objectification is a process that takes place in a social environment as "a response to social power" and which "involves approaching useful social targets regardless of the value of their other human qualities" (Inesi \& Magee, 2008, p. 111). However, in every social situation, more or less, humans act out feelings that are psychosocially formed. Moreover, these feelings can be associated with objectification as "under conditions of power, the criteria for approaching and engaging with other people can shift" from the attributes of the social target to the usefulness of it, "which varies as a function of current goal states" (Inesi \& Magee, 2008, p. 112). This creates challenges for a particular society and culture that force the human ego to adjust to social structures and changes. The adjusting of the Ego involves shared feelings of sameness through collective emotional experiences, and is linked to biological development. As power has its social manifestation, "responses to power include positive appraisals of goal-relevant targets". Power and the approach to it are linked by the emotional feeling of sameness that people experience under one event collectively. Therefore, there should be one focus for everyone (and every human body) that unites all people in feeling and being. The pandemic brought with it a focus on cleanness as a necessary condition for stable health and avoidance of death, thus stressing the importance of risky actions. There is also a focus on the risks of deviating from the rules, as a key to surviving during crisis. So, two skills will need to be applied by every independent individual in this stage of the situationdiscipline and precision. According to Erik Erikson, these skills are learned in the second stage of human development (between 1 and 3 years old) where a sense of autonomy is opposite to feelings of shame and doubt. This is the me-stage. The individual begins to show preferences and to work hard toward independence and autonomy by exploring their own abilities, making decisions and controlling their actions. If they fail- this can lead to low self-esteem and feelings of shame. All this happens in the social environment. Hence, crisis at this stage can be seen to be applicable to the global health crisis of Covid-19. Following Erik Erikson (analysed by George Boeree), in this stage "everything must be done perfectly" and "mistakes must be avoided at all costs" (Boeree, 2006, p. 9). Therefore, during a moment of crisis such as the worldwide lockdown under the spread of disease, up to the moment of compulsion (which is the panic buying of toilet paper- a typical instinctive action), the body has a feeling of doubt. When feeling doubt, the body responds to the question, "Will I survive if...?" A feeling of shame is felt if a mistake is made and at this moment the body responds to the thought, "I will avoid making a mistake if I follow the rules..." The body tries to achieve autonomy through a compulsive physical action - by desperation purchases. And as this conflict happens during the anal stage of development, self-control and self-esteem is widely affected (Boeree, 2006, p. 8). Every individual must balance internally the externally imposed tension. For Erikson "a specific tension will manifest prior to its primary developmental period, and will continue to be relevant after" (Syed \& McLean, 2017, p. 2). Prior to the actual lockdown, people started to buy toilet paper and food. This reflected feelings of doubt about managing the body, its existence in life and its place in relation to its social surroundings. Usual pleasure and leisure were taken away alongside basic human necessities such as freedom of movement, with which the human has unconsciously identified. These are non-normative (unexpected) life events in nature, from which arises a social manifestation of power that objectifies the body as an instrument of its needs. This itself can lead to identity negotiation that is no longer based on its cultural context of development. There is also a moment of understanding the environment and how the body is located within it and corresponds to it. Following Erikson, the development of a sense of autonomy is shaped in an environment and this happens during the second stage of shame and doubt infancy. Therefore, once autonomy is lost, the body loses the sense of control over itself and of its right to exercise it. Through power, this loss of control and autonomy happens at a collective level and becomes a 
moment in which the survival instinct for all people increases to the extent that buying toilet paper does not become only a reaction of survival, but also a reason for aggressive behaviour (fights over toilet paper or particular food in some shops in London). Thus, a lot of the reactions before and around the start of the pandemic were linked with "identity-related issues" that "can certainly arise prior to adolescence" and are related to "self-recognition, self-other integration, and role preference" (Moin \& McLean, 2017, p. 2). All of this is linked to the moment of autonomy, both at a physical and mental level, where the healthy Ego develops around a sense of strong independence in the physical world. Hence, biological aspects of human development are linked with social reality and the way in which power is exercised within that reality. For Erikson this is how the human Ego grows and how social processes and institutions build and mirror inner human growth. Furthermore, the meaning of identity formation, according to Erikson, is linked to an identity crisis, "that can vary according to such social structural factors as social class, subculture, ethnic background, and gender" (Cote \& Levine, 1987, p. 280). It is in this sense that the recent Black Lives Matter movement reflects an identity crisis. The structure of people's past experience repeatedly surfaces, and this activates a fear of witnessing another era of violation, objectification and dehumanization of the human body. This activates the death drive, which the opposing drive (Eros) tends to balance. The dynamic between the two coexisting opposite forces gives rise to an internal connection in human life between destructive and productive forces. Being and appearing to be from one source of action, the two instinctive forces demonstrate that, once awakened by power in its social manifestation, the body has become and object and an instrument. Moreover, objectification is a "response to power that involves approaching social targets more when they are useful" (Inesi \& Magee, 2008, p. 123). Power becomes a "great facilitator" that activates "interpersonal and intrapersonal processes" when the body is in crisis. When the body becomes the target of power, humanity may be put in the "stay alert" state, during which the performance of the experience of self, and the sense of being, are tested not only mentally and psychologically, but also physically and socially.

\subsection{Between Instincts and Crisis}

In all Freud's works, the body is seen through different behaviour mechanisms developed by instincts and through varied psychological foreshortening. One of his views on the body begins with Aristotle's definition of man as "zoon politikon", in which man sees and "realizes" himself only in a community of others (for instance: citizenship, loyalty, community, nation, society).

Whilst Foucault's main focus is power relations between the body and different discourses, seeing it partly as "zoon politikon" (also how Freud sees it in "Civilization and its Discontents") and the system seeing the body as used, Fanon's main focus is how man has developed a behaviour of the "colonized", creating a different identity, which sees the body categorized by colour. Freud's main focus is the body itself as an instrument of the psyche, or in other words how the body acts driven by the psyche, but acting socially. Seeing the psyche as result of transformations of emotions coming from basic sexual impulses, Freud concentrates mainly on the body as a tool of the human "sexual sublimation and desexualisation of the sexual drives" and the body as the locus of the inborn drives which he studied (Dumitrescu, 2013, p. 298). In both there is a moment of objectification due to the fact that the body becomes a focus and a tool. Moreover, Freud demonstrates that the body becomes an object of its own needs and instincts.

In the case of the "Rat man", Freud studied obsessional neurosis through the mind-body connection. Mind is internal. Body is external. The social lies in between. In this case the body is seen mainly as occupied by abnormal obsessive thoughts, ego and sexual desires, observable from early childhood; by the work of defensive mechanisms; and by sexual and erotic instincts, "obsessive, compulsive" fear and the struggle against it. During a crisis, power concentrates in the external to control the internal. In comparison to ideas of the body as an object and focus of power relations in a social context, and of the body as a violated one whose identity is changed in a colonized society in a political-social context, Freud sees the body as an instrument of the brain in a clear psychoanalytical context. In all of his cases, he focuses on the link between mind and body, investigating deeply the reasons for certain behaviour. Nevertheless, even seeing and analysing the body from within different discourses (and acknowledging Foucault's criticism of psychoanalysis), Freud has various common points with Fanon and Foucault - neurosis, violence, aggression, fear, obsession and the body's struggle to deal with these things in real life. Therefore, the human body is the starting point for developing and structuring the mental life of human beings. In a moment of crisis such as war, conflict, restricted rights, lockdown, pandemic, social change, violence, or political coup, the body becomes the "body of rules", having limited freedom (seen by Foucault). It also becomes an object of sedimented prejudices in the oppression of external power (such as the colonizer on the colonized, seen by Fanon). Freud sees the body in a connection between conscious and unconscious, between Ego, Id and Superego, and in the link with childhood and development of the libido (the 
instincts), related to a fixation on a different area of the human body (Hassan, 2013). An interesting instance in Freudian theories is that during the second psychosexual stage (the Anal stage when the Ego develops as well), the child is fully aware that he/ she is a person with rights and wishes. However, connecting to the world, the child needs to resolve the conflict of authority (which each individual learns through the parent figure). This stage repeats itself in its social meaning. Very similar is the situation that humanity experiences during a crisis such as the world lookdowns as a result of the spread of Covid-19 in 2020. In a sense, the body becomes a "body of restrictions". The restrictions around lockdowns are the results of power. And in a restricted reality, power activates human behavioural (and often obsessive) tendencies towards objects such as masks, gloves, types of foods, vaccinations- all linked to protection as a response to the life drive.

A crucial incidence in this crisis is the restriction in freedom of movement, taken away from people by the authorities. Human bodies were suddenly placed back in the Anal stage, to resolve conflict with authority and to control psychosocial moments of shame and doubt; and on top of that is the instinct to survive when control of everyday life is lost. And this urgent situation becomes the period of time before the body's instincts are awakened in the moment of dissolution of life. Then Thanatos is activated by silent triggers and the body starts to exhibit tendencies towards survival as a response from Eros (for example, buying toilet paper and food). The same happens during every period of crisis (such as war), and one example of this is Britain in the autumn of 1917 when "in the early months of the war the price of food soared and panic buying ensued" (Ball \& Hudson, n.d.). History seems to repeat itself; for, in some parts of the world (including Britain), restrictions per person were placed on buying some foods and toilet paper during the pandemic in 2020 - exactly like the restrictions in 1917 established by a food controller (Ball \& Hudson, n.d.). As these restrictions during critical social and political periods increase the human tendency towards survival, the conflict between authority (taking control away by imposing rules, regulations, restrictions) and personal human rights and wishes (the need to be expressed), activates inner drives in the body. As restrictions on freedom of movement of the body increase with time, the instincts, founded in the pleasure principle of Eros (libidinal energy), strive for nothing more than gratification as an end in itself (Marcuse, 1987). These instincts lead the human body to a destructive desire for the relief of tension, the tension we feel having lost freedom. The way toward death is an unconscious escape from pain and desire. The desires of the human being and the reality his body lives in become organized by society, which represses his instinctual need of freedom (by placing restrictions on him). Therefore, the body has become an object of its own desires, needs, instincts and of its own environment.

\subsection{A Violated Body: Loss of Control, a Doubt for Survival}

A violated human body has emerged as a body "unto and into which violence is literal sense". This body is "inscribed into the social politics" in such a way as to "silence the main impact of societal structures of domination and objectification" (Kirkengen, 2001, p. 8). In a moment of domination and objectification, when the power of the body has been taken away, Eros has been suppressed; and that forces more productivity. With additional control by the state and its institutions (for instance, the world lockdown caused by the pandemic), a moment of distress arises. In psychiatry, for instance, this moment of distress may become chronic and linked to anxiety and anger alongside obsession, which is the description of neurosis. In all cases, a result arises.

When the human body does not control its own freedom and impulses, and when it is violated in one way or another, it develops the doubt for survival. For Foucault, neurosis is created by external factors, which are disciplinary discourses (for example, to socially isolate by staying at home) that make constant demands on the body. Therefore, neurosis is created by a "repressive system". This system takes control away and the immediate emotion that is likely to arise from the connection of freedom and basic necessity is the doubt for survival. In this state, according to Freud, neurosis (as a "nearly universal thing" as Oliver states) comes from the circumvention of the basic classes of natural instincts- Eros, the life-drive instinct and Thanatos, the death drive instinct. Therefore, during specific social situations such as genocide, war, or a lockdown as a response to a pandemic (in which human freedom has been taken away and the body has been violated in one way or another through power), there is an uprising moment of fear that creates anxiety and activates Thanatos in order to "re-establish a state of things that was disturbed by the emergence of life" (Freud, 1991).

The violence in each situation is symbolic. It is ordered. It is exercised through power. It has a target. It is objectifying. And it is always available. Foucault sees all forms of violence in relation to a materialization which distributes mechanisms of fear. Foucault draws a clear connection between fear, power and the resistance to power which takes place within its limits. In the same way, in "Discipline and Punish: The Birth of the Prison", he sees the body as used and weak, somehow showing resistance as a result of the power by which, it has been objectified. When fear of authority and loss of control combine in a situation such as the pandemic, this leads to Foucault's idea of 'power creates resistance'. Looking back to human instincts, that resistance, in a social reality 
with no freedom of movement, for example, can be seen in the action of supplying the body with objects that are linked to its instincts.

The work of Fanon, for instance, gives another example of violence- this time not only symbolic, but also physical. Violence against colonialism is a tool, "the highest form of political struggle" and it is seen in the context of exploitation of the colonized nations (Miseweni, 1971, pp. 4-6). Thus, violence is not only political, but also social, and it is discovered in the presentation of certain practices. In contrast, Freud sees violence as being in the nature of the individualistic society. In "Civilization and its Discontents", he analyses the individual-society connection in the context of human nature (Brady, 2012, pp. 4-6). When this nature expresses itself in its societal as well as its biological existence, the human being is left to pursue his natural instincts. Then, Eros is as crucial (in moments even detrimental) as its opposite- Thanatos (Marcuse, 1987, p. 136). And when Thanatos (the destruction of life) rises up, its opposite pole, Eros (the sustaining life drive) overtakes.

\section{Conclusion: Today's Body in Its Performances and Objectifications}

Undoubtedly, the link between body and power as a basic formation of identity has its performative reaction in physical reality. Studying the physical, Freud, Fanon and Foucault see the body from three different perspectives- different in discourse, but closely related in concept. Being objectified in many ways throughout history-"alienate", "colonized", "civilized", "sexualised", "violated", the focus of power and social control brings the body to address its needs and instincts in a situation of crisis.

In Foucauldian thinking, after being "alienated" by the space of work and violated by the demand of things that we need to do on daily basis, we tend to be concentrated more on the physical characteristics of the body tiredness, exhaustion, confusion and lack of sleep. In Fanonian thinking, after being "recognized" by others through our race, class, education, or background, we tend to be concentrated more on the strength and domination that our bodies possess and practice on a daily basis in body and verbal language, actions, decisions, etc. In Freudian thinking, however, after being "pleasured", "sexualised" and "instinctive", bodies tend to look for total materialistic satisfaction and pleasure by allowing themselves to be alienated in a Foucauldian sense, and violated (colonized) in a Fanonian one, by many political and social systems. But in whatever way it has been positioned or circumstanced (being an object of external power or internal drives), the body becomes an instrument of the hidden agitations of the psyche during the crisis of Covid-19. The body responds with an instinctive attitude as a defence towards its environment, and shows a primary frustration that explains human behaviour when the body is objectified and positioned by power. Through emotional turmoil and unconscious chaos, the body shows the repressive element of its libido and, as "time has no power over the id" (Marcuse, 1966, p. 231), its representations have new characteristics in the present. Furthermore, Freud situates "these strivings within an inherent tendency toward self-destruction combated by the reactionary impetus toward growth and greater unification, hence the dialectic of life and death" (Mills, 2006, p. 5). The world crisis caused by Covid-19 has put the human body into everyday situations (such as living under lockdown, restricted movement, restricted rights and freedoms and queuing for basic necessities such as food and toilet paper) that "ultimately make death the first drive" (Mills, 2006, p. 5). During the pandemic, with the protests of the Black Lives Matter movement, this appeared as an "inherent tendency towards self-destruction combated by the reactionary impetus towards growth and greater unification" (Mills, 2006, p. 5). This historical period proves Freud's thinking that Thanatos "cannot fail to be present in every viral process" - only because it is "inherent in the whole process of civilization, just as conspicuously as Eros ensures its survival" (Mills, 2006, p. 5).

It is evident that the prevailing discourse of most past and current affairs in society has emphasized the body as a physical, biological and political tool that forms the social phenomenon of objectification. It is very important to understand that the human body is not split from the mind as it integrates and merges deeply in the concepts of the "self". Moreover, as Jan Wright states, "in poststructuralist terms this is understood by the concept of 'embodied subjectivity' where those social practices which form selves work through language and material practices to locate individual subjects in relation to institutional and cultural discourses" (Wright, 2000, p. 1). Therefore, the body becomes a product of these discourses as well as an instrument of them and this is the actual moment of objectification that provokes the activation of Thanatos. Collectively, this creates active indicators for the discourses that objectify the human body, such as demolishing statues, fighting for toilet paper, increasing depression and mental breakdown, awakening of inner fears, protesting, rioting, etc. - in which social events the body locates itself as holding the power for change, but from the position of being objectified by power itself.

To conclude, the body has always been a subject of power. This is because it reflects and shows social changes in every historical period. The body also plays an important role in collective memory as it structures a view not only of the group about itself, but also about the other. However, the body has appeared as an instrument to 
question the humanistic idea, becoming a subject of distortion, a subject of trauma and a point of the "presumed opposition between civilization and individual happiness" (Freud, 2002, p. 3), in which civilization, life and individual happiness live in profound incompatibility. Thus, one of the contributions of this article is explaining psychosocially one of the modern examples of 'body- power' relation by providing a deeper view on internal invisible processes behind social events that have changed the world. These events and processes have changed the inner and the outer world personally and collectively through different examination of power- that reinforces objectification in which the body is an instrument on its own, but within the relation to the other bodies. That is why they had to be directed when and how to practice social distancing from each other and how to exist in the public sphere. Therefore, this paper has added more insight into the process of objectification. Moreover, it has proved Michel Foucault's words in "Power and Knowledge: selected interviews and other writings" (by Colin Gordon), where Foucault explains that "the great fantasy is the idea of a social body constituted by the universality of wills. Now the phenomenon of the social body is the effect not of a consensus but of the materiality of power operating on the very bodies of individuals" (Foucault, 1980, p. 59).

\section{References}

Alessandrini, A. (2009). The Humanism Effect: Fanon, Foucault, and Ethics without Subjects. Foucault Studies, 7 , 64-80. https://doi.org/10.22439/fs.v0i7.2637

Armstrong, A. (2021). Michel Foucault: Feminism. The Internet Encyclopaedia of Philosophy. Retrieved from https://iep.utm.edu/foucfem/

Ball, C., Hudson, N., West Sussex, \& the Great War Project. West Sussex County Council. Retrieved from https://www.westsussexpast.org.uk

Bertorelli, D. (2020). A pandemic of panic... and hope. A journey from hopelessness to a new start. The World before and after Covid: Intellectual reflections of politics, diplomacy and international relations. EIIS.

Binder, K., Crego, D. M., Eckert, G., Kotanidis, S., Manko, R., \& Del Monte, M. (2020). States of emergency in response to the coronavirus crisis: Situation in certain Member States. EPRS (European Parliamentary Research Service), PE 649.408.

Binkley, S. (2016). Anti-racism beyond empathy: Transformations in the knowing and governing of racial difference. Subjectivity, 9, 181-204. https://doi.org/10.1057/sub.2016.4

Boeree, G. (2006). Erik Erikson: Personality Theories. Shippensburg University. Retrieved from https://www.social-psychology.de/do/pt_erikson.pdf

Brady, K. (2017). Sigmund Freud: Suppressing the Violent Tendencies of Humanity through Governance. Retrieved from https://www.academia.edu/4314683/Sigmund_Freud_Suppressing_the_Violent_Tendencies_of_Humanity_ through_Governance

Burman, E. (2016). Fanon, Foucault, feminisms: Psychoeducation, theoretical psychology, and political change. Theory \& Psychology, 26(6), 706-730. https://doi.org/10.1177/0959354316653484

Buss, D. (2003). The evolution of desire. Revised and expanded edition.

Cologero, R. M. (2012). Objectification Theory, Self-Objectification, and Body Image. Encyclopedia of Body Image and Human Appearance, p. 574. https://doi.org/10.1016/B978-0-12-384925-0.00091-2

Cote, J., \& Levine, C. (1987). A Formation of Erikson's Theory of Ego Identity Formation. Developmental Review, 7(12), 273-325. The University of Western Ontario, Canada. https://doi.org/10.1016/0273-2297(87)90015-3

Dilek, A. (2017). Explanation and understanding of human aggression: Freudian psychoanalytical analysis, Fromm's Neo-Freudian perspective and Bandura's Social Learning Theory. International Journal of Social Science and Economic Research, 2(1), 2151-2164.

Dumitrescu, M. (2013). The relationship between body and soul from the perspective of Freud's psychoanalysis. Procedia - Social and Behavioral Sciences, 92(10), 294-298. https://doi.org/10.1016/j.sbspro.2013.08.675

Elliott, A. (1998). Freud 2000. Polity Press.

EU Commission. (2020). Coordinated economic response to the COVID-19 Outbreak. Retrieved from https:/www.finat.com/documents/632/communication-coordinated-economic-response-covid19-march-202 0 -en.pdf 
EU Parliament. (2020). EU coordinated action to combat the COVID-19 pandemic and its consequences. Retrieved from https://www.europarl.europa.eu/doceo/document/TA-9-2020-0054_EN.pdf

Fanon, F. (1961). The Wretched of the Earth. Translated by Farrington C. Retrieved from https://www.openanthropology.org/fanonviolence.htm

Fanon, F. (1986). Black skin, white masks. Pluto Press.

Foucault, M. (1979). Discipline and punish; the birth of the prison. Vintage Book Edition.

Foucault, M. (1984). The care of self: The History of Sexuality 3. Editions Gallimard.

Foucault, M. (1984). The use of pleasure. Editions Gallimard.

Freud, S. (1991). Case Histories 2, Rat Man. Penguin Books.

Freud, S. (1991). On Sexuality. Penguin Books.

Freud, S. (1991). The essentials of psychoanalysis. Penguin Books, England.

Freud, S. (2002). Civilization and its discontents. Penguin Books.

Fuery, O., \& Mansfield, N. (1997/1998). Cultural Studies and the New Humanities: Concepts and Controversies. Oxford University Press.

Gibson, N. (2016). Why Frantz Fanon Still Matters, Failure \& Reciprocity, The Critique. Black Lives Matter (Part II): Understanding The New Movement For Racial Justice. Retrieved from https://www.thecritique.com/articles/why-frantz-fanon-still-matters/

Gordon, G. (1980). Michel Foucault: Power/Knowledge: Selected interviews and other writings, 1972-1977. Pantheon Books. USA.

Gray, R. (2009). Freud's Libidinal Phases of Psycho-Sexual Development. Freud and Literary Imagination. German 390/Comp. Lit 396/Engl 363/Chid 498/Jsis 488/Lit 298. Retrieved from https://courses.washington.edu/freudlit/Libido.html

Gray, R. (2017). Lecture Notes: Civilization and Its Discontents, German 390/Comp. Lit. 396/Engl 363/CHID 498/JSIS 488/Lit 298. Retrieved from https://courses.washington.edu/freudlit/Civilization.Notes.html

Hassan, E. (2013). Freud's Psychosexual Stages of Development. Walden University, USA.

Herbert, M. (1987). Eros and civilisation, Ark Paperbacks. London.

Honeth, A. (1991). Foucault and Adorno: Two forms of the critique of modernity, (translated by David Roberts). Retrieved from https://journals.sagepub.com/doi/pdf/10.1177/072551368601500104

Horney, K. (1991). Neurosis and Human growth: the struggle towards self-realisation. Norton and Company Ltd. USA.

Hutt, R. (2020). The coronavirus fallout may be worse for women than men. Here's why. World Economic Forum. Retrieved from https://www.weforum.org

Inesi, E., \& Magee, J. (2008). Power and the Objectification of Social Targets. Journal of Personality and Social Psychology, 95(1), 111-127. https://doi.org/10.1037/0022-3514.95.1.111

Internet Encyclopaedia of Philosophy (IEP). (2016). A peer-reviewed academic source. Retrieved from https://www.iep.utm.edu/foucfem/

Jones, L-K. (2020). \#BlackLivesMatter: An analysis of the Movement as social drama. Humanity \& Society, 44(1), 92-110. https://doi.org/10.1177/0160597619832049

Jutten, T. (2016). Sexual Objectification. Ethics, 127(1), 27-49. https://doi.org/10.1086/687331

Kahna, S., \& Liefooghea, A. (2013). Thanatos: Freudian manifestations of death at work. Culture and Organization, 20(1), 53-67. https://doi.org/10.1080/14759551.2013.853064

Kirkengen, A. (2001). Inscribed bodies. Klower Academic Publishers, USA. https://doi.org/10.1007/978-94-017-1886-8

Kli, M. (2018). Eros and Thanatos: A Non-dualistic Interpretation: The Dynamic of Drives in Personal and Civilizational Development from Freud to Marcuse. Psychoanalytic Review, 105(1). https://doi.org/10.1521/prev.2018.105.1.67 
Kwon, Y-Hee. (2007). Eros and Psyche: Freud's Configuration of the Sexual Drive and the Body-Ego. Department of English, Seoul National University.

Langton, R. (2011). Sexual Solipsism: Philosophical Essays on Pornography and Objectification. Oxford University Press.

Majchrzyk, M. (2012). Eros and Thanatos - Desires and Fears. Institute of Philosophy. Sveikatos Mokslai, 22(2), 107-113. Cardinal Stefan Wyszyński University, Warsaw, Poland.

Mambrol, N. (2017). Sigmund Freud and Trauma Theory. Literary theory and Criticism, (3). Retrieved from https://literariness.org/2017/06/21/sigmund-freud-and-the-trauma-theory/

Marcuse, H. (1966). Eros and civilization. Beacon Press. Boston. Retrieved from https://www.sas.upenn.edu/ cavitch/pdf-library/Marcuse_Eros_and_Thanatos.pdf

McNally, D. (2001). Bodies of Meaning: Studies of Language, Labour and Liberation. State University of New York. Retrieved from https://books.google.co.uk/books?id=nY9Vq3DWbt8C\&pg=PA8\&lpg=PA8\&dq=how+freud+sees+the + hu man+body\&source=bl\&ots=dPIUaRaJaP\&sig=kuCNxKY4dZ_zgJYhCJp8YHHkNMg\&hl=bg\&sa=X\&ved $=0$ ahUKEwj7ufrnqavRAhVEGsAKHUTFA7gQ6AEIUDAG\#v=onepage $\& \mathrm{q}=$ how $\% 20$ freud $\% 20$ sees $\% 20$ th e\%20human\%20body\&f $=$ false

McNay, L. (1992). Foucault and Feminism: Power, gender and the Self. Polity Press.

Mills, J. (2006). Reflections of the death drive. Adler School, Toronto Society of Contemporary Analysis. Psychoanalytic Psychology, 23(2), 373-382. https://doi.org/10.1037/0736-9735.23.2.373

Minerbo, M., \& Pertiga, P. (2007). Two faces of Thanatos; Broken flower (2005) and Ai no corrida (1976). Int J Psychoanalysis, 88, 777-790.

Museweni, Y. (2017). Fanon's theory on violence: its verification in liberated Mozambique. In N. M. Shamuyarira (Ed.), Essays on the Liberation of Southern Africa (pp. 1-24). Retrieved from https://www2.bc.edu/ lugira/Fanon's\%20Theory\%20on\%20Violence\%20PDF.pdf

Naranjo, C. (1994). Character and Neurosis: An Integrative View. Gateways Publishers, USA.

Prati, G., \& Mancini, A. D. (2021). The psychological impact of COVID-19 pandemic lockdowns: a review and meta-analysis of longitudinal studies and natural experiments, Cambridge University Press. Psychological Medicine, 51, 201-211. https://doi.org/10.1017/S0033291721000015

Schwab, K., \& Malleret, T. (2020). Covid-19: The Great Reset. World Economic Forum.

Stanford Encyclopaedia of Philosophy (SEP). (2010). Theories of Meaning. Retrieved from https://plato.stanford.edu/entries/meaning/

Syed, M., \& McLean, K. (2017). Erikson's Theory of Psychosocial Development.

Syed, M., \& McLean, K. (2018). Erikson's theory of psychosocial development. In E. Braaten (Ed.), The SAGE encyclopedia of intellectual and developmental disorders (pp. 578-581). SAGE Publications, Inc., https://www.doi.org/10.4135/9781483392271.n178

Thomas, D., \& Zuckerman, A. (2018). Black lives matter in Community Psychology, Glob. Persp. Community Psychology in Global Perspective (CPGP), 4(2), 1-8.

Tirsahar, P. (2017). Death Drive in Psychoanalysis versus Existential Psychotherapy. Psychology and Behavioural Science, International journal, 8(1). University of Tutor, UK. https://doi.org/10.19080/PBSIJ.2017.08.555726

Tolstoy, L. (1899). What is Art? Chapter 4, translated by Alymer Maude.

Urist, J. (2014). Which death matter? The Atlantic Global. Retrieved from https://www.theatlantic.com

Veer et al. (2021). Psycho-social factors associated with mental resilience in the Corona lockdown. Translational Psychiatry, 11(1). https://doi.org/10.1038/s41398-020-01150-4

Wright, J. (2000). Disciplining the body: power, knowledge and subjectivity in a physical education lesson. University of Wollongong. 


\section{Notes}

Note 1. Thanatos from Greek means 'death'. In Freudian meaning, this is the death drive in human nature that controls aggression and risky behaviours- activities that people engage in to get closer to death.

Note 2. Eros from Greek means 'love'. In Freudian meaning, this is the life drive (opposite to the death drive) in human nature that activates affection, prosocial actions, and social cooperation and compels people to engage in actions that sustain their lives and are linked to health and safety.

Note 3. Dehumanization is "to deprive someone of human qualities, personality", according to the Oxford dictionary (lack of humanity).

Note 4. Dehumanize is "to remove or reduce human involvement or interaction in something, such as process or place", "to make people feel like objects", according to the Oxford dictionary (lack of altruism).

\section{Copyrights}

Copyright for this article is retained by the author(s), with first publication rights granted to the journal.

This is an open-access article distributed under the terms and conditions of the Creative Commons Attribution license (http://creativecommons.org/licenses/by/4.0/). 